\title{
Decadal-Timescale Estuarine Geomorphic Change Under Future Scenarios of Climate and Sediment Supply
}

\author{
Neil K. Ganju • David H. Schoellhamer
}

Received: 24 August 2009/Revised: 18 October 2009/Accepted: 16 November 2009/Published online: 19 December 2009

(C) The Author(s) 2009. This article is published with open access at Springerlink.com

\begin{abstract}
Future estuarine geomorphic change, in response to climate change, sea-level rise, and watershed sediment supply, may govern ecological function, navigation, and water quality. We estimated geomorphic changes in Suisun Bay, CA, under four scenarios using a tidal-timescale hydrodynamic/sediment transport model. Computational expense and data needs were reduced using the morphological hydrograph concept and the morphological acceleration factor. The four scenarios included (1) present-day conditions; (2) sea-level rise and freshwater flow changes of 2030; (3) sea-level rise and decreased watershed sediment supply of 2030; and (4) sea-level rise, freshwater flow changes, and decreased watershed sediment supply of 2030. Sea-level rise increased water levels thereby reducing wave-induced bottom shear stress and sediment redistribution during the wind-wave season. Decreased watershed sediment supply reduced net deposition within the estuary, while minor changes in freshwater flow timing and magnitude induced the smallest overall effect. In all future scenarios, net deposition in the entire estuary and in the
\end{abstract}

N. K. Ganju ( $ه)$

Coastal and Marine Geology Program, US Geological Survey,

Woods Hole, MA 02543-1598, USA

e-mail: nganju@usgs.gov

N. K. Ganju • D. H. Schoellhamer

Department of Civil and Environmental Engineering,

University of California, Davis,

Davis, CA 95616, USA

D. H. Schoellhamer

US Geological Survey,

Placer Hall, 6000 J Street,

Sacramento, CA 95819, USA

e-mail: dschoell@usgs.gov shallowest areas did not keep pace with sea-level rise, suggesting that intertidal and wetland areas may struggle to maintain elevation. Tidal-timescale simulations using future conditions were also used to infer changes in optical depth: though sea-level rise acts to decrease mean light irradiance, decreased suspended-sediment concentrations increase irradiance, yielding small changes in optical depth. The modeling results also assisted with the development of a dimensionless estuarine geomorphic number representing the ratio of potential sediment import forces to sediment export forces; we found the number to be linearly related to relative geomorphic change in Suisun Bay. The methods implemented here are widely applicable to evaluating future scenarios of estuarine change over decadal timescales.

Keywords Numerical modeling · Geomorphology

Scenarios $\cdot$ Sediment transport

\section{Introduction}

Estuarine geomorphology partially dictates ecological function (Roy et al. 2001; Saintilan 2004; Lopez et al. 2006), navigation, and water quality (Chubarenko and Tchepikova 2001; Le et al. 2007). The past and future trajectory of an estuary's geomorphology may be directly controlled by anthropogenic activities (e.g., dredging, watershed modification) or changes in environmental forcing (e.g., sea-level rise, benthic structure). Simulating estuarine geomorphic change, however, is complicated by a relative lack of calibration data, computational expense, and uncertainty. Several recent studies have laid the groundwork for developing robust calibration and simulation methods for estuarine geomorphic change (Hibma et al. 2003; Lesser et al. 2004; Roelvink 2006; Ganju et al. 2009). Once a 
robustly calibrated model is available, it can be applied to scenarios of changes in anthropogenic or environmental forcing.

The response of estuarine geomorphology to future scenarios of climate change, sea-level rise, and decreasing sediment supply is unknown. Future climatic changes over the western USA, specifically precipitation and air temperature, will alter the timing and magnitude of freshwater flows (Knowles and Cayan 2002) and therefore the timing and magnitude of sediment supply to estuaries. Accelerated sea-level rise (Meehl et al. 2007) will increase depth, salinity intrusion, and inundation of intertidal areas, thereby modulating the hydrodynamics and sediment transport in those areas. Worldwide, human activity in many watersheds has reduced sediment supply to estuaries and coastal seas due to trapping behind dams and soil conservation measures (Walling 2006). How these changes will affect geomorphic evolution (and therefore ecological function, navigation, and water quality) can be evaluated using a robust numerical model of hydrodynamics and sediment transport. Evaluating changes in geomorphology in response to future scenarios can be done by differencing the results of a base-case scenario simulation and a future scenario simulation. Therefore, the goal is not a concrete prediction of future change but a possible scenario of change under prescribed future conditions.

Suisun Bay, CA (Fig. 1), provides a unique opportunity for evaluating estuarine geomorphic response under scenarios of change. Hydraulic mining in the nineteenth century released large quantities of sediment causing major perturbations to the geomorphology of the bay (Gilbert 1917). These perturbations are still working through the system; the most recent set of bathymetric surveys, between 1942 and 1990, showed about $0.6 \mathrm{~m}$ of net erosion averaged over the entire bay, which is ostensibly erosion of the hydraulic mining deposits. Considering climatic changes over the western USA, ongoing sea-level rise, and decreasing sediment loads, the future geomorphic evolution of Suisun Bay will dictate the sediment availability to sensitive habitats such as tidal wetlands and intertidal mudflats, the shape of navigation channels, and the extent of salinity intrusion. Ganju et al. (2009) idealized, calibrated, and applied the Regional Ocean Modeling System to hindcasting geomorphic change in Suisun Bay over the 1867-1887 period. In this study, we implement those methods to simulate four scenarios of future change: (1) present-day conditions; (2) sea-level rise and freshwater flow changes of 2030; (3) sea-level rise and decreased watershed sediment supply of 2030; and (4) sea-level rise, freshwater flow changes, and decreased watershed sediment supply of 2030. "Climate Change, Sea-Level Rise, and Watershed Sediment Supply Effects on Estuaries" outlines the general effect of these changes on estuarine sediment transport;
"Site Description" describes the setting of Suisun Bay; "Hydrodynamic/Sediment Transport Model" and "Methods" describe the general and specific aspects of the numerical modeling, respectively; "Results" details the modeling results for each scenario; "Discussion" discusses the mechanisms for geomorphic change, ramifications for ecological modeling, and basin-scale geomorphic change.

\section{Climate Change, Sea-Level Rise, and Watershed Sediment Supply Effects on Estuaries}

\section{Climate Change}

Because most of California's water is derived from snowmelt (stored in reservoirs), the condition of snowpack (i.e., thickness, water content) is critical for the state's water supply. Knowles and Cayan (2002) showed that future warming scenarios will cause significant snowpack loss thereby altering the runoff regime in California. The slight increase in temperature causes a greater fraction of precipitation to fall as rain rather than snow. This shift causes the freshwater flow hydrograph to represent accentuated rainfall-related peaks and dampened snowmeltrelated peaks.

Freshwater flows from the watershed are responsible for the majority of new sediment input to many estuaries (Wright and Nittrouer 1995). In stratified or partially mixed estuaries, the timing and magnitude of flows can significantly alter the vertical and lateral circulation, thus modulating sediment transport within the estuary. In many estuaries the peak freshwater pulse is responsible for delivering an annual pulse of sediment and also transporting estuarine sediment seaward (e.g., Krone 1979; Woodruff et al. 2001). If the precipitation regime over the watershed changes in response to climate change, the timing and magnitude of these flow and sediment pulses will change. Sustained drought will reduce watershed sediment supply possibly changing the net direction of sediment transport within the estuary. Ignoring water management effects, the estuary would become more oceanic in nature, and salinity and near-bed convergence of flow and sediment would propagate landward. Conversely, the estuary would become more riverine during a prolonged wet period, encouraging net seaward sediment transport.

\section{Sea-Level Rise}

Along the California coast, data from the twentieth century show a $2-\mathrm{mm} /$ year trend of increasing sea level (Flick et al. 2003; Ryan et al. 1999), though yearly mean sea level can fluctuate due to atmospheric and oceanic patterns (e.g., El 
Fig. 1 San Francisco Bay and subembayments Central Bay, San Pablo Bay, and Suisun Bay. Suisun Bay is the landwardmost subembayment, adjacent to the Sacramento and San Joaquin River Delta

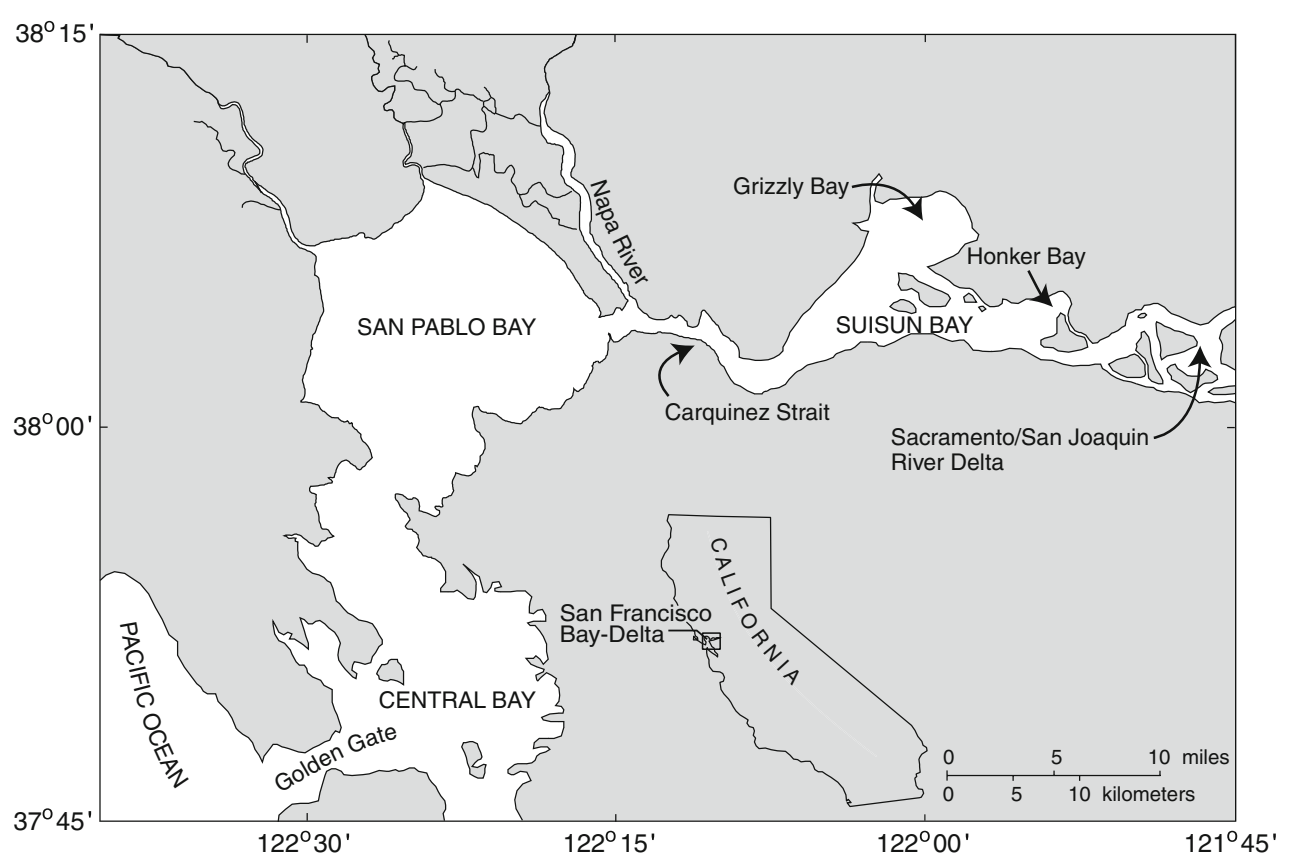

Nino Southern Oscillation). Sea-level rise directly affects estuaries by modulating water levels within the estuary. Simas et al. (2001) simulated salt marsh development under sea-level scenarios and found mesotidal salt marshes to be threatened under worst-case scenarios; they found that marshes accustomed to large tidal ranges are less sensitive to relatively small mean increases in sea level, assuming sediment input is not limited. Pont et al. (2002) reinforced the importance of mineral (inorganic) input in light of sealevel rise; they suggest that current sediment supply from the Rhone River is not sufficient to maintain marsh elevation at its mouth. Pethick (1993) used changes induced by tectonic sea-level rise to infer changes induced by global warming-related sea-level rise; he found intertidal profiles shifting landward, while the estuarine channels became wider and shallower. Landward movement in biological communities also suggested an overall more oceanic condition. In the Kennebec River estuary, slowing sealevel rise shifted the estuary towards ebb dominance, leading to net seaward sediment transport (Fenster and Fitzgerald 1996). If sediment inputs are not sufficient, wetlands will recede and regress towards the land (Pethick 1993; Day et al. 1999). Because sea-level rise is a gradual process, it may be that estuaries can accrete fast enough and not increase in volume. But this is dependent on sediment inputs, mainly from the watershed.

\section{Watershed Sediment Supply}

Anthropogenic activities in many watersheds have reduced the delivery of sediment from the watershed to estuaries and coastal seas (Walling 2006). The construction of dams on some the world's major rivers (e.g., Nile River, Colorado River), have completely eliminated net sediment loads past the dams. Several studies have quantified the effect of sediment supply on estuarine geomorphology. Guillén and Palanques (1997) investigated the evolution of the Ebro River mouth in response to decreased river discharge and sediment loads during the twentieth century and found the deltaic shoreline to be in retreat. Accretion in the Yangtze River Delta decreased in response to decreased river discharge and sediment load; the outer subaqueous Delta was generally more sensitive than the inner portion (Yang et al. 2003). In San Francisco Bay, the landward subembayments Suisun and San Pablo Bays have responded to hydraulic mining and subsequent load decreases by depositing rapidly and then subsequently eroding (Cappiella et al. 1999; Jaffe et al. 1998; Jaffe et al. 2007). The reduction of the hydraulic mining pulse and construction of dams led to a $50 \%$ decrease in sediment supply from the Sacramento River between 1957 and 2004 (Wright and Schoellhamer 2004). Exchange between estuarine subembayments may be more important in the coming century as watershed sediment loads continue to decrease (Ganju and Schoellhamer 2006).

\section{Site Description}

While the reservoirs in California are responsible for water storage, the Sacramento and San Joaquin River Delta is where the water transfer (export) facilities are located. The 
Delta is a complex network of natural and engineered channels, with control gates, pumps, and levees. Tidal forcing from the Pacific Ocean propagates into the Delta though tidally averaged salinity rarely exceeds 2 , due to freshwater flow management. Recent studies on sediment transport in the Delta (Wright and Schoellhamer 2004, 2005) established a sediment budget for the Delta which demonstrates its current depositional nature. Reduced sediment supply from the watershed, due to a reduction in mining debris and sediment trapping behind dams, will reduce the amount of sediment trapped in the Delta, though trapping efficiency (fraction of input retained) may remain constant. Currently, net yearly trapping efficiency is inversely proportional to net yearly flow volume, i.e., the greater the freshwater flow, the lower the trapping efficiency. Sediment loads from the Delta have been decreasing since the peak of hydraulic mining and may continue to decrease into this century.

Suisun Bay is the landward-most subembayment of San Francisco Bay and extends from the Sacramento and San Joaquin River Delta at the landward end to Carquinez Strait at the seaward end (Fig. 1). Suspended-sediment transport within Suisun Bay follows a seasonal cycle: the majority of suspended sediment is delivered through the Delta during the large, winter freshwater flows; a portion deposits in the Delta, while the remaining sediment is exported through Suisun Bay to San Pablo Bay. During the following summer months, reliable onshore winds generate wind-waves, resuspending bed sediments in both the Suisun and San Pablo Bays. Due to the greater portion of shallows in San Pablo Bay, there is a gradient of soluble solids content (SSC) from west to east (between San Pablo and Suisun Bays), and with landward near-bed flows, these combine to transport sediment up-estuary to Suisun Bay. As the summer progresses, the finer fraction of the erodible bed sediment pool is reduced. In the fall when neither wind nor freshwater flow is significant, SSC is at its lowest. As the wet season commences during winter, the cycle repeats (Krone 1979; Ganju and Schoellhamer 2006).

\section{Hydrodynamic/Sediment Transport Model}

The Regional Ocean Modeling System (Shchepetkin and McWilliams 2005) is a public-domain hydrodynamic model which is coupled with the Community Sediment Transport Modeling System (CSTMS; Warner et al. 2008). The full details of the model are beyond the scope of this work; the reader is directed to several primary sources, as well as the open source code itself (www.myroms.org), for model details. Modeling details specific to this application are detailed in "Methods" below.
Warner et al. (2008) detail the entire sediment transport module and bed-updating procedure. Along with the advection-diffusion equation for suspended-sediment transport, source and sink terms are applied for bed erosion and deposition, following Ariathurai and Arulanandan (1978). In suspended load simulations with no bedload transport, such as this study, the erosive or depositional sediment flux at the bed-water interface is multiplied against a morphological acceleration factor (Hibma et al. 2003; Lesser et al. 2004; Roelvink 2006) to calculate an accelerated bed-level change. This scales up the evolution of bed change but does not alter suspended-sediment concentrations within the water column. The only feedback is between the hydrodynamic field, the newly calculated bathymetry, and bed composition, all of which are updated at every time step. Combined wave-current shear stresses are computed using the method of Madsen (1994). The specification of wave heights is discussed in "Methods."

\section{Methods}

For all scenarios, modeling parameters were held constant at the values established by Ganju and Schoellhamer (2009), which were used for modern simulations of sediment fluxes (Table 1). Though there is uncertainty involved with using parameters that are difficult to quantify

Table 1 Model parameters for all scenario simulations

\begin{tabular}{ll}
\hline Model parameter & Value \\
\hline \# of $x$-direction cells, size range & $160,72-394 \mathrm{~m}$ \\
\# of $y$-direction cells, size range & $87,102-593 \mathrm{~m}$ \\
\# of $z$-direction cells & 4 \\
Baroclinic time step & $40 \mathrm{~s}$ \\
Barotropic time step & $2 \mathrm{~s}$ \\
Simulation steps & 788,400 \\
Settling velocity & $0.10 / 0.25 \mathrm{~mm} \mathrm{~s}^{-1}$ \\
Erosion rate & $2 \times 10^{-5} \mathrm{~kg} \mathrm{~m}^{-2} \mathrm{~s}^{-1}$ \\
Bed critical shear stresses & $0.10 / 1.0 \mathrm{Nm}^{-2}$ \\
Porosity & 0.60 \\
Bed density & $2,000 \mathrm{~kg} \mathrm{~m} \mathrm{~m}^{-3}$ \\
Initial bed thickness & $2.0 \mathrm{~m}$ \\
Wave period & $1.425 \mathrm{~s}$ \\
Wave fetch & $20 \mathrm{~km}$ \\
Water depth (for wave model) & Evolving bathymetry \\
Tidal boundary velocity, stage & Flather (radiation) \\
River boundary velocity, stage & Flather (radiation) \\
Tidal boundary tracers & Clamped \\
River boundary tracers & Clamped \\
Morphological acceleration factor & 20 \\
\hline & \\
\hline
\end{tabular}


(e.g., critical shear stress), a sensitivity analysis will address uncertainty as it relates to scenarios of change.

\section{Modeling Domain}

The Sacramento/San Joaquin Delta represents a complex domain with multiple channels, open-water areas, flow gates, and export pumps. Realistically representing the Delta in the model would more than double the domain and require further parameterization for in-Delta hydrodynamic processes. Due to the constraints mentioned above, we simplified the Delta in previous studies (Ganju and Schoellhamer 2009; Ganju et al. 2009) as a single, continuous channel (Fig. 2). Those studies demonstrated that sediment transport processes through the Delta to Suisun Bay were unaffected by this idealization.

Carquinez Strait, immediately landward of the Napa River (Fig. 1), was chosen as the seaward boundary of the domain. Eastern Carquinez Strait is subject to complex circulation dynamics due to geometry of the Strait as well as baroclinic effects. Suspended-sediment dynamics in Carquinez Strait are sensitive to the formation of an estuarine turbidity maximum on the north side of the Strait (Schoellhamer and Burau 1998).

\section{Idealized Time-Stepping: Morphological Hydrograph and Morphological Factor}

Computational expense was reduced for simulations at decadal timescales. Here, we used two idealizations: the morphological hydrograph (Ganju et al. 2009) and the morphological acceleration factor (Hibma et al. 2003; Lesser et al. 2004; Roelvink 2006). The morphological hydrograph refers to a limited set of one or more hydrographs that, when used as input to the model, generates the same geomorphic change as the full set. Ganju et al. (2009) found that three morphological hydrographs served adequately for a simulation of 1867-1887 bathymetric change in

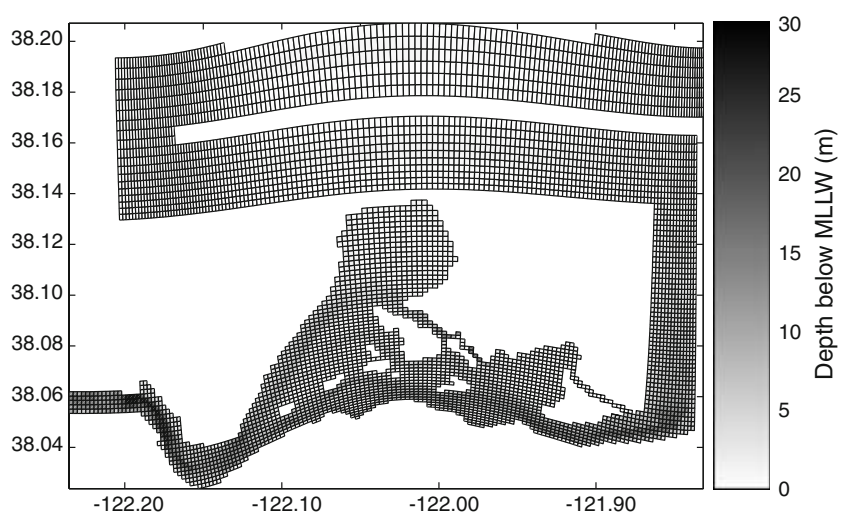

Fig. 2 Computational grid of Suisun Bay, in ROMS orthogonal, curvilinear format. Depth is referenced to mean lower low water, with bathymetry of 1990 (Cappiella et al. 1999)
Suisun Bay. The other modification is the use of a morphological acceleration factor. At each time step, the calculated bed sediment fluxes are scaled up by the factor to produce an accelerated bed change, and the bathymetry used by the hydrodynamic module is updated. By using a $\mathrm{MF}=20$ and a simulation time of 1 year, the changes computed for all morphological hydrographs can be averaged to yield the simulated 20-year change. The efficacy of the morphological acceleration factor and the morphological hydrograph, with $\mathrm{MF}=20$ and a simulation time of 1 year, was confirmed with field data by Ganju et al. (2009).

Implementation of Landward and Seaward Boundary Conditions

\section{Scenario B: Base-Case}

Landward Boundary Conditions Using the concept of the morphological hydrograph, three years were selected to represent the 1990-2010 period: a dry year (2001), a moderate year (1999), and a wet year (2006) (Table 2; Fig. 3). These years were selected based on peak flows and sediment loads: the average of the peak flows and sediment loads of 1999, 2001, and 2006 are close to the average peak flows and sediment loads of the 1990-2006 period. This provides a low, middle, and high sediment load morphological hydrograph. Total load and peak flow magnitude are the features of greatest relevance for simulating estuarine geomorphic change apart from tidal and wind-wave forcing (Ganju et al. 2009); therefore, the use of three morphological hydrographs that span these extremes is sufficient. The measured sediment loads of the Sacramento and San Joaquin rivers were specified at the boundary.

Seaward Boundary Conditions The idealizations for tidal stage, velocity, salinity, and SSC used by Ganju and Schoellhamer (2009) and Ganju et al. (2009) were implemented here. Tidal harmonics provided an appropriate initial estimate of historic tidal elevations and velocities. The seaward salinity gradient was calculated as a function of freshwater flow, following Warner et al. (2005). Three signals were superimposed to recreate a synthetic time series of seaward SSC: a flow signal that peaks in the early spring, a seasonal wind-wave signal that peaks in the summer, and a spring-neap signal that is a function of tidal energy (obtained from tidal harmonics). The time series was then modulated by a mean yearly SSC which is linearly related to total sediment input from the Delta during the water year.

Sediment Bed Parameters We used the same values as Ganju and Schoellhamer (2009), with the same spatial distribution of two sediment classes. A fine sediment class (with a relatively low critical shear stress) and a coarse sediment 
Table 2 Total and peak flow and sediment load characteristics of morphological hydrographs and represented period (1990-2006)

\begin{tabular}{lccc}
\hline Period & Yearly total flow $\left(10^{9} \mathrm{~m}^{3}\right)$ & Peak flow $\left(\mathrm{m}^{3} / \mathrm{s}\right)$ & Yearly sediment load (Mt) \\
\hline MH 1 (1999) & 27.80 & 4,054 & 2.02 \\
MH 2 (2001) & 8.56 & 1,600 & 0.75 \\
MH 3 (2006) & 54.03 & 11,538 & 3.65 \\
Average of MHs & 30.13 & 5,730 & 2.14 \\
Average of 1990-2006 & 23.74 & 5,133 & 2.22 \\
\hline
\end{tabular}

class (with a relatively higher critical shear stress) were distributed with an initial 40/60 split in Suisun Bay and a 20/ 80 split in areas deeper than $7 \mathrm{~m}$. Limited modern data preclude the specification of detailed sediment distributions in the bed. Nonetheless, the difference between scenarios should be relatively insensitive to these initial conditions. These initial conditions were identical for all scenarios.

Atmospheric Forcing Spectral analysis of hourly winds in Suisun Bay showed three predominant wind frequencies: seasonal, weekly, and daily. A synthetic time series was developed using these three signals (Ganju et al. 2009). The wind speed was provided to the model, which then calculates the fetch-limited wave height using the Shore Protection Manual method (Coastal Engineering Research Center 1984). Fetch was held constant at $20 \mathrm{~km}$, and wave period was also held constant at $1.425 \mathrm{~s}$. This value was established in previous modeling efforts, as it resulted in the best agreement with observed bathymetric change (Ganju et al. 2009). Water depth is utilized in this computation, using the evolving bathymetry and water surface elevation. This accounts for feedback between geomorphic evolution and wave-induced bottom stress. No waves were specified over the idealized Delta.

\section{Scenario WS: Warming and Sea-Level Rise by 2030}

Landward Boundary Conditions The three morphological hydrographs were scaled to represent the warming conditions modeled by Knowles and Cayan (2002). Simulations representing 1967-1987 flows, with 2030 temperature conditions, were compared to the same flows adjusted to 2000 conditions. This provided a scaling curve for the hydrograph that modulates a current hydrograph to 2030 conditions. All three hydrographs were scaled using this curve. Again, the measured sediment loads of the Sacramento and San Joaquin rivers will be specified at the boundary. Total yearly sediment input was conserved with this approach; the only difference is the timing and magnitude of the flows and sediment loads. This approach did not take into consideration management response to the altered snowpack regime. It should be noted that these hydrograph changes are relatively minor compared to the estimated hydrograph changes of 2060 and 2090 (Knowles and Cayan 2002).

Seaward Boundary Conditions The only modification made at the seaward boundary for this simulation was the addition of $0.06 \mathrm{~m}$ to the tidal elevation time series, at the
Fig. 3 Hydrographs and sediment loads for base-case and 2030 conditions, for three morphological hydrographs (1999, 2001, 2006)
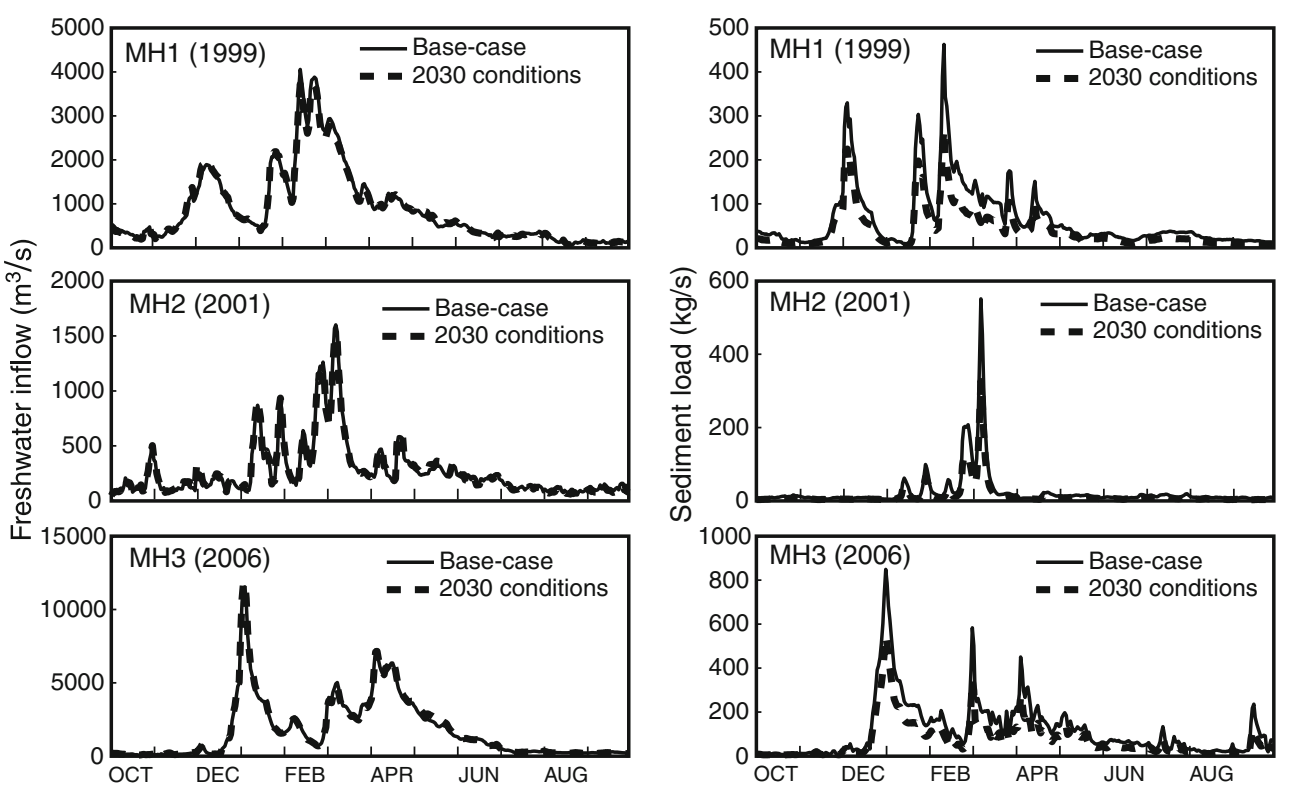
seaward boundary, to represent sea-level rise by 2030 . This is a relatively conservative estimate, based on the current trend of $0.002 \mathrm{~m} /$ year (over a 30 -year period) at the Golden Gate. It may be possible that the relationship between freshwater flow and salinity gradient established earlier may change with sea-level rise; however, there are no field or simulation data available to estimate this change. The increase in water level at the seaward boundary should represent the possible increased salt intrusion adequately.

\section{Scenario DS: Decreased Sediment Supply and Sea-Level}

Rise by 2030

Landward Boundary Conditions Using the base-case hydrographs (no warming signal), we altered the sediment loads to represent a decrease in sediment supply by scaling the SSC boundary condition. To estimate the reduction in sediment supply, we extended the decrease identified by Wright and Schoellhamer (2004), which was $50 \%$ in 44 years, to a period 30 years in the future. This method yields a decrease of $34 \%$ over the next 30 years, and this factor was applied to the measured sediment load time series (Fig. 3).

Seaward Boundary Conditions The sea-level rise changes made in the previous section were retained here, and we modulated the seaward SSC function to represent a decrease in watershed sediment loads, as described by Ganju et al. (2009).

\section{Scenario WDS: Warming, Decreased Sediment Supply, and Sea-Level Rise by 2030}

Landward Boundary Conditions For this simulation, the modified hydrographs (warming signal), along with the decreased SSC boundary condition, were used (Fig. 3). The SSC modification does not account for detailed changes in watershed sediment production that may be associated with climatic change. Sources of sediment supply will vary as climatic patterns shift over the large watershed, but modeling of that type was not attempted here.

Seaward Boundary Conditions The sea-level rise and seaward SSC changes made in the previous section were retained here.

\section{Sensitivity Analysis}

The goal of scenario modeling is not predicting absolute bathymetry but relative changes in water depth and bed level due to warming, sea-level rise, and decreased sediment supply. Therefore, the goal of the sensitivity analysis is to compare changes between two scenarios with the original parameters and changes between the two scenarios with perturbed parameters. If the changes are similar, then incorrect parameter specification has a minor effect on the changes between scenarios of geomorphic change. The original geomorphic change results, $\Delta h(\xi)$, are defined as

$\Delta h(\xi)=\Delta h(\xi)_{\text {base-case }}-\Delta h(\xi)_{\text {future }}$

and the sensitivity analyses results, $\Delta h\left(\xi+\xi^{\prime}\right)$, as

$\Delta h\left(\xi+\xi^{\prime}\right)=\Delta h\left(\xi+\xi^{\prime}\right)_{\text {base-case }}-\Delta h\left(\xi+\xi^{\prime}\right)_{\text {future }}$

where $\Delta h(\xi)_{\text {base-case }}$ is the base-case climate run with the original parameters, $\Delta h(\xi)_{\text {future }}$ is the future run with the original parameters, $\Delta h\left(\xi+\xi^{\prime}\right)_{\text {base-case }}$ is the base-case climate run with perturbed parameters, and $\Delta h\left(\xi+\xi^{\prime}\right)_{\text {future }}$ is the future run with perturbed parameters. Under a parameter perturbation, if we can show that

$\Delta h(\xi) \sim \Delta h\left(\xi+\xi^{\prime}\right)$

then the geomorphic change results are insensitive to parameter specification, and the differences of geomorphic scenarios behave linearly.

Sensitivity analyses on one major parameter for both scenarios B and WDS (warming, decreased sediment supply, sea-level rise) were performed in this fashion. The difference between the base-case and future scenario with original parameters and perturbed parameters were compared. We used wave period as the parameter of choice because previous studies established that sediment fluxes were most sensitive to this parameter (Ganju and Schoellhamer 2009). Wave period was decreased by $10 \%$ (favoring deposition), and morphological hydrographs for scenarios B and WDS were simulated.

\section{Results}

Specific and Bulk Changes in Sedimentation for Each Scenario

\section{Scenario B: Differences Between Morphological Hydrographs}

The composite net geomorphic change for the three morphological hydrographs was $0.163 \mathrm{~m}$ (Table 3), with individual changes of $0.09 \mathrm{~m}$ (2006), $0.12 \mathrm{~m}$ (1999), and $0.27 \mathrm{~m}$ (2001). Net deposition was a function of peak and total freshwater flow, with the driest year (2001) being the most depositional. For all three morphological hydrographs, deposition was observed in all depth ranges shallower than $11 \mathrm{~m}$ (Table 3). Deeper areas were more erosional in the wettest year (2006). The composite result is closest to the 
Table 3 Bed-level (BL) and relative water depth (RWD) changes for all scenarios; changes are relative to scenario B

\begin{tabular}{|c|c|c|c|c|c|c|c|c|}
\hline $\begin{array}{l}\text { Depth } \\
\text { range (m) }\end{array}$ & Area $\left(\mathrm{km}^{2}\right)$ & $\begin{array}{l}\text { Sc. B } \\
\text { BL (m) }\end{array}$ & $\begin{array}{l}\text { Sc. WS BL } \\
\text { change (m) }\end{array}$ & $\begin{array}{l}\text { Sc. WS RWD } \\
\text { change }(m)\end{array}$ & $\begin{array}{l}\text { Sc. DS BL } \\
\text { change (m) }\end{array}$ & $\begin{array}{l}\text { Sc. DS } \\
\text { RWD change }\end{array}$ & $\begin{array}{l}\text { Sc. WDS BL } \\
\text { change }(\mathrm{m})\end{array}$ & $\begin{array}{l}\text { Sc. WDS RWD } \\
\text { change }(\mathrm{m})\end{array}$ \\
\hline $0-2$ & $45.72(48 \%)$ & 0.018 & 0.026 & 0.034 & 0.019 & 0.041 & 0.018 & 0.042 \\
\hline $2-4$ & $13.08(14 \%)$ & 0.366 & -0.003 & 0.063 & -0.014 & 0.074 & -0.017 & 0.077 \\
\hline $4-6$ & $11.98(13 \%)$ & 0.192 & -0.013 & 0.073 & -0.029 & 0.089 & -0.031 & 0.091 \\
\hline $6-8$ & $8.05(11 \%)$ & 0.329 & -0.007 & 0.067 & -0.030 & 0.090 & -0.032 & 0.092 \\
\hline $8-10$ & $6.65(7 \%)$ & 0.481 & 0 & 0.060 & -0.027 & 0.087 & -0.028 & 0.088 \\
\hline $10-12$ & $5.15(5 \%)$ & 0.320 & 0.003 & 0.057 & -0.035 & 0.095 & -0.034 & 0.094 \\
\hline $12-14$ & $2.17(2 \%)$ & 0.167 & -0.006 & 0.066 & -0.029 & 0.089 & -0.029 & 0.089 \\
\hline $14-16$ & $1.12(1 \%)$ & -0.189 & -0.010 & 0.070 & -0.031 & 0.091 & -0.030 & 0.090 \\
\hline $16-18$ & $0.73(<1 \%)$ & -0.215 & -0.013 & 0.073 & -0.030 & 0.090 & -0.030 & 0.090 \\
\hline $18-20$ & $0.13(<1 \%)$ & 0.697 & -0.041 & 0.101 & -0.026 & 0.086 & -0.033 & 0.093 \\
\hline Total & 94.76 & 0.163 & 0.010 & 0.050 & -0.004 & 0.064 & -0.005 & 0.065 \\
\hline
\end{tabular}

Positive BL values indicate deposition, positive RWD values indicate deepening, with sea-level rise included

intermediate year (1999). The largest area in terms of depth interval, $0-2 \mathrm{~m}$, was slightly depositional for all three morphological hydrographs and the composite result. While there are no observational data that represent the post-1990 bathymetric survey, the composite yearly change of $+0.008 \mathrm{~m} /$ year $(0.163 \mathrm{~m}$ over 20 years $)$ is of the same order as the observations of Cappiella et al. (1999), which found average bathymetric changes in Suisun Bay to be $-0.007 \mathrm{~m} /$ year between 1867 and 1990. It should be reiterated that we are not attempting absolute predictions of geomorphic change, so the results of scenario B are not intended to simulate the actual trajectory of geomorphic change over the next 20 years.
Anomalies of modeled change (Fig. 4) suggest that dry years (MH 2) favor enhanced deposition in the seaward portions of Suisun Bay, while wet years (MH 3) favor enhanced deposition in the landward portions of Grizzly and Honker Bays. Channels are relatively more erosional in the wet year and less erosional for the dry year.

\section{Scenario WS: Effect of Warming and Sea-Level Rise}

Slight changes in the hydrograph and a step increase in sealevel rise induced an increase in net deposition and bed level of $0.01 \mathrm{~m}$ (Table 3). However, relative water depth increased by $0.05 \mathrm{~m}$, indicating an overall deeper estuary,
Fig. 4 Composite bathymetric change result and anomalies (as compared to composite) of the three morphological hydrographs
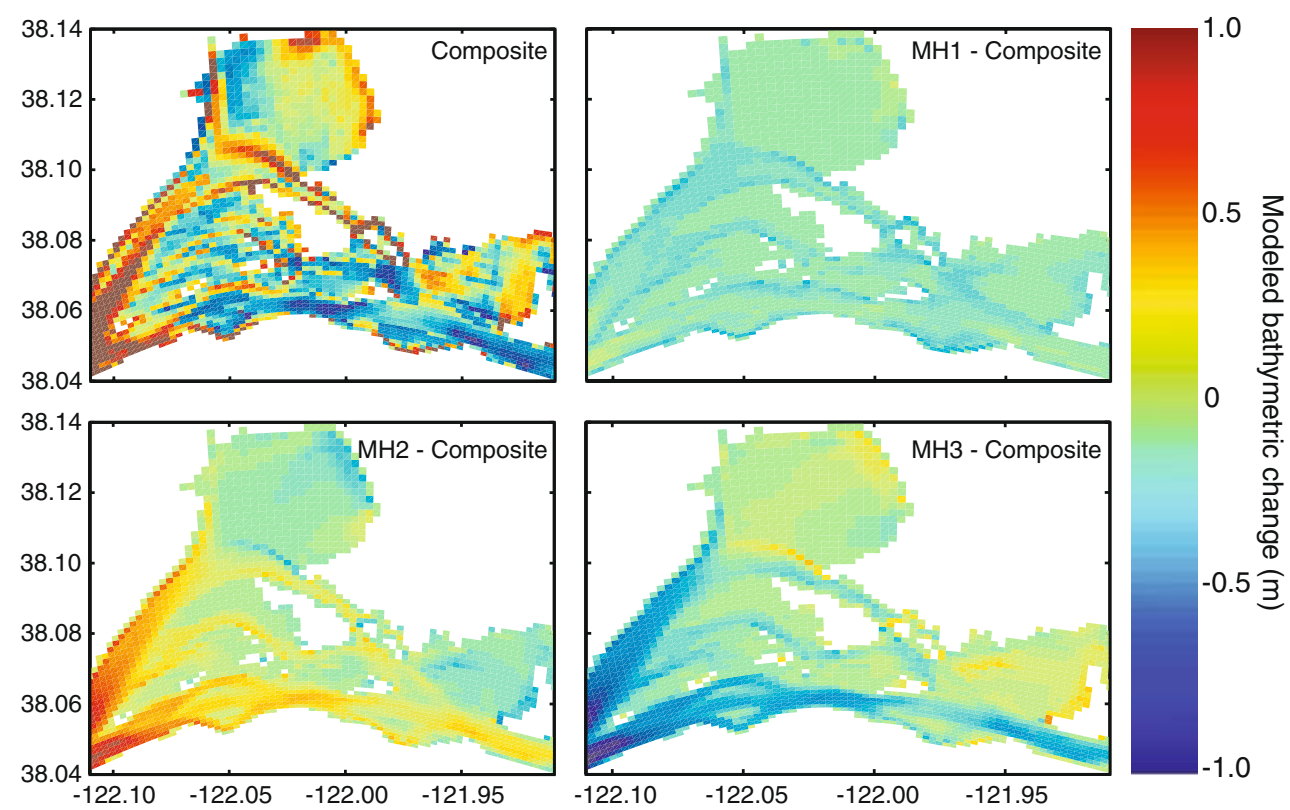
due to the prescribed sea-level rise. The bed-level changes, in 2-m depth intervals, suggest that sea-level rise (the dominant forcing in this scenario) induces more deposition in shoal areas $(+0.026 \mathrm{~m}$ in the $0-2 \mathrm{~m}$ depth interval), and less deposition in all other areas. However, in order to keep pace with the prescribed rise in sea level, bed-level change would need to average $0.06 \mathrm{~m}$ over the entire domain. The net increase in deposition of $0.01 \mathrm{~m}$ suggests that sediment supply cannot maintain elevations relative to sea-level rise.

While the expanses of Grizzly and Honker Bays show an increase in deposition, the shallowest fringes of Grizzly Bay are less depositional in this scenario (Fig. 5). Increases in water level reduce the effect of wind-wave resuspension, as areas become deeper and wave-induced bottom shear stress is reduced. The changes in water level, in Grizzly Bay, led to a $9 \%$ reduction in peak wave orbital velocity (from 0.119 to $0.108 \mathrm{~m} / \mathrm{s}$ ) during the wind-wave season. Therefore, less redistribution and more deposition are observed in the shallowest areas. Shoreline erosion is not accounted for in the model, though it may be important as sea level increases. Most of Suisun Bay is fringed by levees or marshes; future management decisions may affect the exposure of the shoreline in response to sea-level rise.

\section{Scenario DS: Effect of Decreased Sediment Supply and Sea-Level Rise}

A reduction in watershed sediment supply, coupled with sea-level rise, led to $0.004 \mathrm{~m}$ less deposition than scenario $\mathrm{B}$ and $0.014 \mathrm{~m}$ less deposition than scenario WS (Table 3). Relative water depth increased by $0.064 \mathrm{~m}$ due to reduced deposition and sea-level rise. The increase in sea level (and decrease in wave orbital velocities) still increased deposition in the shallowest depth interval relative to scenario B, but a reduction in sediment supply from the watershed and seaward sources decreased deposition in all other areas of Suisun Bay, nearly uniformly in areas deeper than $4 \mathrm{~m}$ (Table 3).

Reducing watershed sediment supply, while keeping other forcings constant, decreases net sediment transport into Suisun Bay from the landward end, leading to decreased deposition (Table 3). The effect of reduced watershed sediment supply was greatest for the MH 3 simulation (24\% reduction in deposition), which had the largest sediment load, and the smallest effect was observed during the MH 2 simulation (4\% reduction in deposition), which had the lowest sediment load. The seaward SSC boundary condition, which is partially a function of watershed sediment supply, is reduced for the decreased sediment supply scenario and therefore leads to a decrease in deposition at the seaward end of Suisun Bay (Fig. 5).
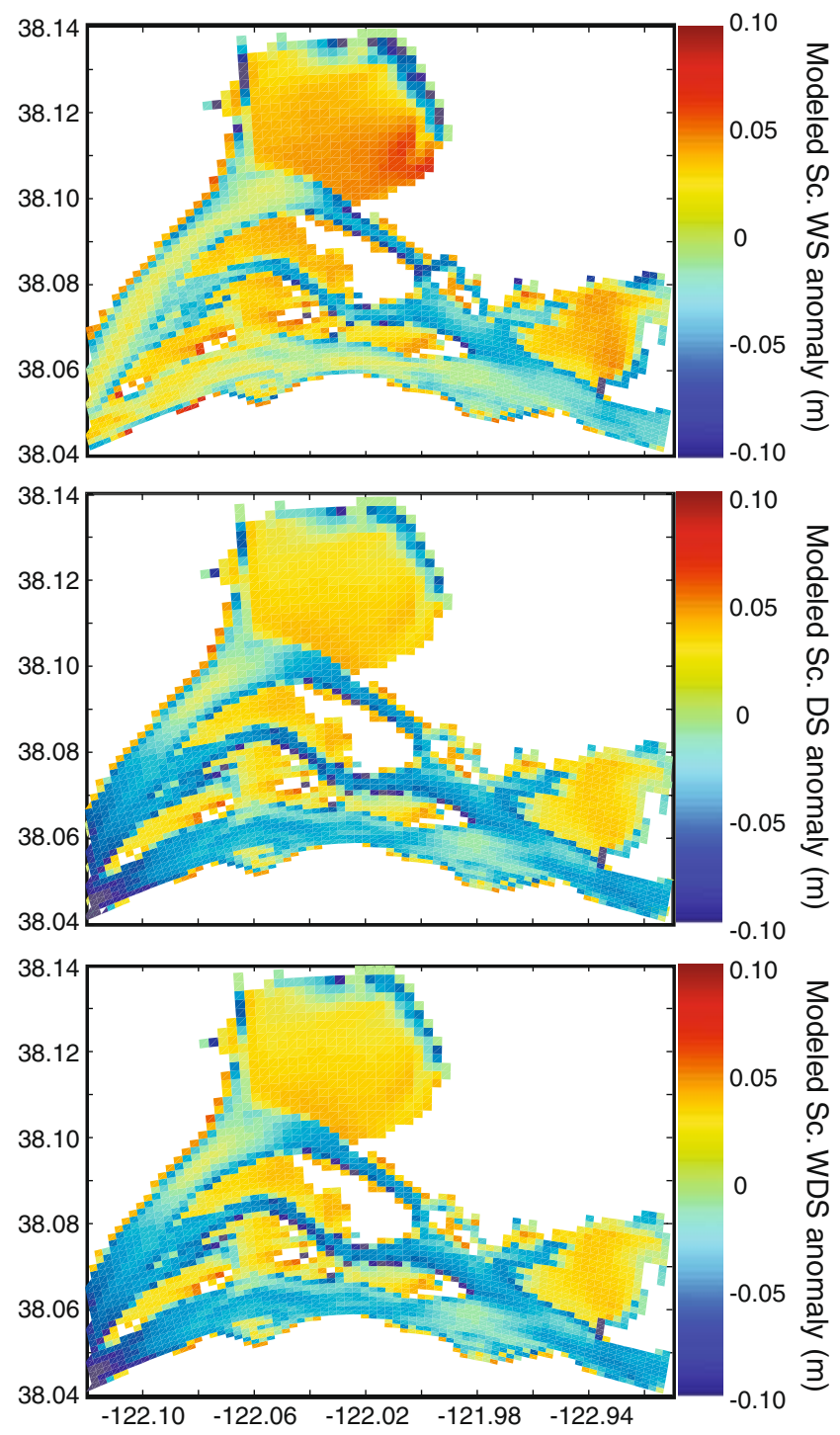

Fig. 5 Anomalies, relative to scenario B, of bathymetric change for three scenarios

\section{Scenario WDS: Effect of Warming, Decreased Sediment} Supply, and Sea-Level Rise

The combined effect of warming, decreased sediment supply, and sea-level rise led to a net decrease in deposition, from the base-case scenario, of $0.005 \mathrm{~m}$ (Table 3). Relative water depth increased by $0.065 \mathrm{~m}$. The shallowest $2 \mathrm{~m}$ of Suisun Bay was still more depositional, while all other intervals were less depositional (Table 3). The overall change in net deposition between scenario DS and this scenario is slight $(0.001 \mathrm{~m})$ but is attributed to increased seaward flow velocities during the episodic freshwater flows. The minor differences between this scenario and scenario DS, which are caused by the altered timing and magnitude of freshwater flows, are discussed 
below. It should be noted that this change is less than $1 \%$ of the net bed change in the simulation.

\section{Sensitivity Analysis}

A $10 \%$ decrease in wave period results in a geomorphic difference change, $\Delta h\left(\xi+\xi^{\prime}\right)-\Delta h(\xi)$, of $-0.003 \mathrm{~m}$ over the entire domain (Table 4). The largest effect is seen in the 0-2 $\mathrm{m}$ depth interval, suggesting that the relationship between wave period, bottom shear stress, and subsequent transport is most critical in the shallowest depths. It should be noted that these changes are all less than $0.01 \mathrm{~m}$, over a 20 -year morphologically accelerated simulation. For reference, the net bed-level changes for the four scenarios used in this analysis ranged between 0.158 and $0.193 \mathrm{~m}$, while the $10 \%$ decrease in wave period increased deposition from 0.163 to $0.193 \mathrm{~m}$ for scenario B (an increase of 18\%). Sutherland et al. (2004) cite bathymetric measurement errors ranging between 0.026 and $0.1 \mathrm{~m}$ for modern surveys. The net difference of $0.003 \mathrm{~m}$ over 20 years is well below the error of measurements and is therefore considered reasonable. In addition, the uncertainty in future sea-level rise (Meehl et al. 2007) far outweighs the error from differencing scenario results. This exercise indicates that uncertainty in modeling parameters, when considering scenarios of change, creates errors that are still substantially less than other typical sources of error, such as field measurement and prediction of sea-level rise.

\section{Discussion}

Comparison of Dry and Wet Year Geomorphic Change

Greater deposition is observed in dry years because the seaward source of sediment, San Pablo Bay, is dominant when freshwater flows are decreased. Despite a decreased seaward SSC boundary condition in dry years, the other contributors to seaward SSC (wind-wave and tidal energy) remain and allow for significant landward sediment transport. Watershed sediment loads are in decline (Wright and Schoellhamer 2004), while San Pablo Bay has a pool of available sediment (Jaffe et al. 2007). In dry years, landward transport becomes more important, and Suisun Bay turns more estuarine: the seaward end of Suisun Bay becomes more depositional, and watershed sediment loads become less important. In wet years, Suisun Bay becomes more riverine: seaward residual velocities are increased, contributing to greater sediment export during episodic freshwater flows. Those flows are nonetheless capable of redistributing sediment towards the off-channel shoals, which are relatively more depositional during wet years. If future climatic changes induce prolonged wet or dry periods, this will change the relative importance of seaward and watershed sediment sources.

\section{Effect of Sea-Level Rise: Scenario B vs. Scenario WS}

Sea-level rise, prescribed at the seaward boundary, propagates through the domain and deepens the estuary. While wave generation and propagation in an irregularly shaped estuary are complex, a relative deepening should reduce bottom orbital velocities (which reduces resuspension). Depending on the wave model used, the geomorphic response will vary. With the simple wave model used here, a $0.06 \mathrm{~m}$ increase in the seaward tidal elevation boundary condition leads to a $9 \%$ decrease in peak orbital velocity during the summer, in Grizzly Bay. In systems with significant intertidal area and tidal marsh, sea-level rise will possibly increase the availability of sediment to landward portions of these habitats. However, if supply is limited, the marsh surface will not accrete fast enough to keep up with the rise.

In these simulations, the net increase in deposition in the shallowest areas $(0-2 \mathrm{~m})$ was $0.026 \mathrm{~m}$, while relative water depth increased by $0.034 \mathrm{~m}$. The increase in deposition at
Table 4 Sensitivity analysis results, comparing nonperturbed and perturbed simulations (scenario B and scenario WDS), with wave period perturbed by a $10 \%$ decrease

\begin{tabular}{lcccc}
\hline Depth range $(\mathrm{m})$ & Area $(\%)$ & $\Delta h(\xi)(\mathrm{m})$ & $\Delta h\left(\xi+\xi^{\prime}\right)(\mathrm{m})$ & Change $(\mathrm{m})$ \\
\hline $0-2$ & 48 & 0.018 & 0.009 & -0.009 \\
$2-4$ & 14 & -0.017 & -0.021 & -0.004 \\
$4-6$ & 13 & -0.031 & -0.023 & +0.008 \\
$6-8$ & 11 & -0.032 & -0.026 & +0.006 \\
$8-10$ & 7 & -0.028 & -0.025 & +0.003 \\
$10-12$ & 5 & -0.034 & -0.033 & +0.001 \\
$12-14$ & 2 & -0.029 & -0.028 & +0.001 \\
$14-16$ & 1 & -0.030 & -0.031 & -0.001 \\
$16-18$ & $<1$ & -0.030 & -0.031 & -0.001 \\
$18-20$ & $<1$ & -0.033 & -0.031 & +0.002 \\
Total & 100 & -0.005 & -0.008 & -0.003 \\
\hline
\end{tabular}


these depths was less in the decreased watershed sediment supply scenario $(0.018 \mathrm{~m})$, and relative water depth increased by $0.042 \mathrm{~m}$, suggesting that the shallowest areas cannot keep up with sea-level rise, under present or future sediment supply conditions. It is necessary, however, to investigate intertidal sediment transport with more robust wetting/drying and wave propagation schemes, to estimate the change in mudflat profile or marsh accretion. Wavebreaking on mudflats and marsh trapping of sediment are major processes that are not considered here and may change sediment transport on the estuary fringe.

\section{Effect of Warming: Scenario DS vs. Scenario WDS}

Though the climatic effect on snowpack is relatively minor over the next two decades, we have represented the changes in the hydrograph. Indeed, the effect on geomorphic change is minor (Fig. 6): a net decrease in deposition of $0.001 \mathrm{~m}$ is simulated. It is important to note that this result is concurrent with sea-level rise and decreased sediment loads. Spatially, the greatest difference is observed in the landward sections of Grizzly Bay. These extremely minor changes are attributed to the change in water levels throughout Grizzly Bay, which are affected by the change
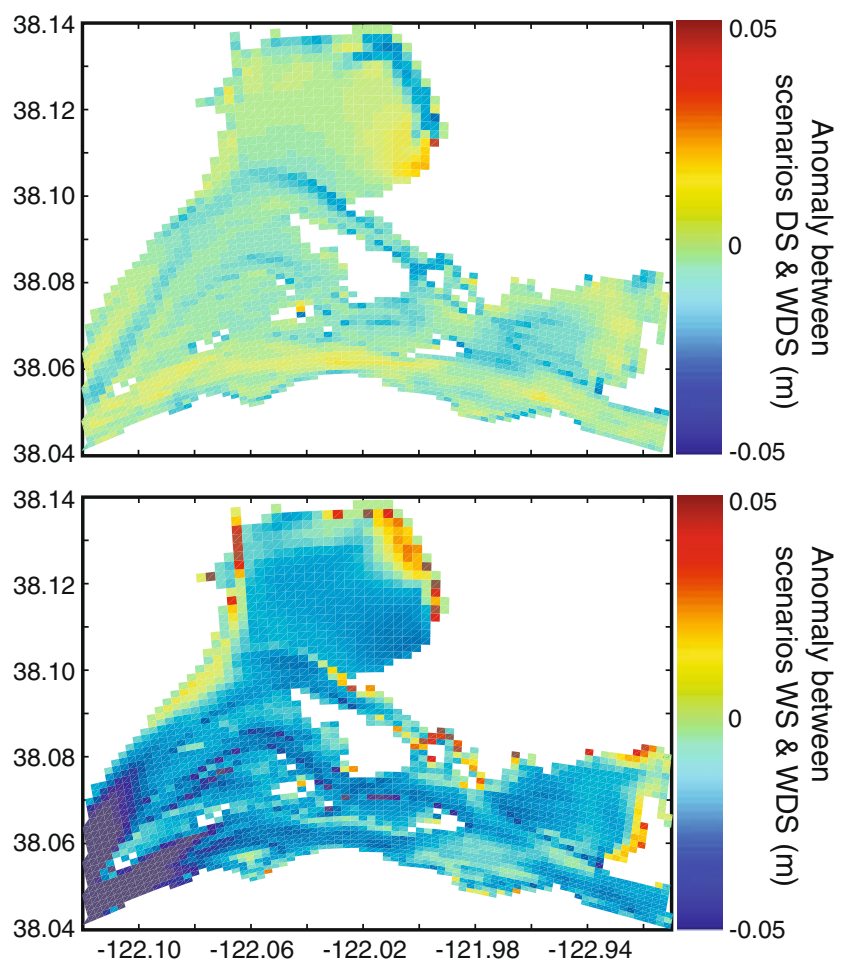

Fig. 6 Anomaly between scenarios DS and WDS (showing the effect of warming and altered hydrograph) and anomaly between scenarios WS and WDS (showing the effect of decreased watershed sediment supply) in hydrographs between the two scenarios. The relative changes in water levels, combined with depth-dependent wave-induced resuspension, combine to create these anomalies. Under the more extreme snowpack changes by the end of this century (Knowles and Cayan 2002), it is possible that these interactions will be less important than the overall shifting of greater sediment loads earlier in the water year and reduced sediment loads later in the water year. Assuming a stationary wind signal, the relative timing of sediment loads and the wind-wave season may be more important than minor changes in water level.

\section{Effect of Decreased Sediment Loads: Scenario WS vs. Scenario WDS}

With other forcings constant, reduced sediment supply from any boundary will result in a net decrease in deposition within an estuary. Depending on the magnitude of the reduction and the distance between the boundary and the estuary, the reduction may be linear or weakly nonlinear. For example, the reduction in deposition for MH 2, under the decreased sediment supply scenario, was only $4 \%$ but $24 \%$ for $\mathrm{MH}$ 3. The greater freshwater flow in $\mathrm{MH} 3$ allowed watershed-derived sediment to reach and bypass Suisun Bay, whereas the low freshwater flow of MH 2 did not supply much sediment to Suisun Bay regardless of the load. Because MH 3 provided a substantial amount of sediment to Suisun Bay, under present conditions, the decreased sediment supply under 2030 conditions is more evident in the geomorphic changes of Suisun Bay.

The combined anomaly (Fig. 6) is dominated by the signal from $\mathrm{MH}$ 3, which had the largest reduction in deposition. Most areas of Suisun Bay became less depositional due to a reduction in loads past Mallard Island and reduction of landward transport through Carquinez Strait. However, isolated portions of Grizzly and Honker Bay were more depositional. Interaction between sediment supply, deposition, and wind-wave resuspension are responsible for these variations: with a reduction in sediment supply, landward areas of Grizzly Bay are relatively deeper at the end of the freshwater flow period (before the windwave period). This relative increase in depth leads to a lesser influence of wave orbital velocities on the bed, leading to less erosion during the summer. This echoes the idea from above: the timing of sediment delivery relative to the summer wind-wave period may be important in decadal-timescale geomorphic change.

\section{Changes in Optical Depth}

Changes in bathymetry, water level, and suspendedsediment concentrations may indirectly alter ecological function due to changes in optical depth. Optical depth 
(OD), which is inversely proportional to mean light irradiance, is defined as

$\mathrm{OD}=D k_{\mathrm{t}}$

where

$k_{\mathrm{t}}=k_{\mathrm{ssc}}+k_{\mathrm{p}}$

and $D$ is total water depth $(\mathrm{m}), k_{\mathrm{t}}$ is the light attenuation coefficient $\left(\mathrm{m}^{-1}\right)$, and $k_{\mathrm{ssc}}$ and $k_{\mathrm{p}}$ are the light attenuation contributions of suspended sediment and phytoplankton, respectively (Cloern 2007). Furthermore,

$k_{\mathrm{ssc}}=a_{\mathrm{ssc}} \mathrm{SSC}$

where $a_{\text {ssc }}$ normally falls in the range of 0.05 and 0.06 (J. Cloern, written communication); background turbidity not associated with SSC is ignored here. Optical depth indicates the ecological function of a given habitat, between autotrophic (primary production, OD $<10$ ) and heterotrophic (secondary production, OD $>20$ ) (Cloern 2007). Changes in optical depth due to future scenarios were estimated by simulating tidal-timescale turbidity with current and future bathymetry. Because of the overall deeper conditions (favoring increased optical depth) and decreases in sediment supply (favoring decreased optical depth) in scenario WDS, increases in optical depth indicate that deepening outweighs decreases in turbidity; conversely, a decrease in optical depth suggests that despite deeper conditions, reductions in turbidity dominate.

Two cases were simulated here, using MH 3: (1) base: the present-day MH3 hydrograph, sea-level rise, and sediment load conditions for 1 year, with the 1990 bathymetry; and (2) future: the $2030 \mathrm{MH} 3$ hydrograph, sea-level rise, and sediment load conditions with the final, evolved bathymetry from scenario WDS. Mean optical depths over the entire water year were calculated assuming $k_{\mathrm{p}}=0$ and $a_{\mathrm{ssc}}=0.05$. As an indicator of overall system function, we compared the total areas of regions with OD $<10$ and OD $>20$. In the base simulation, $48 \%$ of Suisun Bay and the western Delta were characterized by a mean OD $<10$, while $37 \%$ were characterized by OD $>20$. In contrast, the future simulation yielded $50 \%$ of the area with OD $<10$ and $36 \%$ with OD $>20$. The overall effect was a $2 \%$ increase in autotrophic habitat and a $1 \%$ decrease in heterotrophic habitat under the prescribed scenario. The increase in low-OD area is attributed to the overall decline in suspended-sediment concentrations (due to decreased watershed sediment supply), especially in the shallower areas of Suisun Bay (where wave energy is reduced due to increased sea level). Sea-level rise acts to increase OD, while decreased sediment supply (and therefore decreased SSC) acts to decrease OD; therefore, these two forces counteract each other to yield relatively small changes in OD.
Estuarine Geomorphic Number

The model simulations performed in this study and previous hindcasting efforts demonstrate a dynamic interaction between sediment supply and erosional processes. Sediment supply and depth appear to be the critical variables, assuming constant tidal and wind-wave forcing. This enables us to generate a general relationship between relative geomorphic change and geomorphic change processes. We define the relative geomorphic change, $\Delta h_{\mathrm{R}}$, as

$\Delta h_{\mathrm{R}}=\frac{\Delta h}{h}$

where $\Delta h$ is the net geomorphic change in 1 year, and $h$ is the mean estuary depth.

Variables supporting negative geomorphic change (sediment export) include tidal energy, represented by the tidal prism $Q_{\mathrm{p}}$; the area-to-depth ratio $A / h$; and consolidation processes, represented by bed dry bulk density, $\rho_{\mathrm{d}}$. An increase in tidal prism (due to a landward levee failure, for example) will tend to enhance tidal velocities and therefore shear stresses within the seaward portion of the embayment; a basin with a large area-to-depth ratio will be relatively shallow and broad, allowing for greater influence of wind-waves on bed resuspension.

Variables supporting positive geomorphic change (sediment import) include a representative sediment input concentration, $Q_{\mathrm{s}} / Q$, where $Q_{\mathrm{s}}$ is the total sediment input and $Q$ is the total freshwater flow; basin volume, $V$ (or $A h$ ); and mean depth, $h$. In a basin with fixed boundaries, volume increases are a result of deepening and should promote deposition. Overall increases in mean depth should reduce shear stress induced by wind-waves, though this is an oversimplification for basins with complex geometry.

Grouping these variables and expressing as a ratio of import $\left(Q_{\mathrm{s}} / Q, A h, h\right)$ to export $\left(Q_{\mathrm{p}}, A / h, \rho_{\mathrm{d}}\right)$ yields a dimensionless estuarine geomorphic number, $E_{\mathrm{h}}$, as follows:

$E_{\mathrm{h}}=\frac{1}{\rho_{\mathrm{d}}} \frac{Q_{\mathrm{s}}}{Q} \frac{h^{3}}{Q_{\mathrm{p}}}$

The relationship between $E_{\mathrm{h}}$ and $\Delta h_{\mathrm{R}}$ may vary with basin and sedimentary properties but is approximately linear for Suisun Bay (Fig. 7). We use estimated data for sediment supply (Ganju et al. 2008) and the data of Cappiella et al. (1999) for mean depth and net geomorphic change (Table 5). Tidal prism estimates are taken from the modeling results described here. A dry bulk density of $529 \mathrm{~kg} / \mathrm{m}^{3}$ is used here (Krone 1979). This metric is a simplistic yet useful tool for evaluating the relative effect of altered freshwater flow magnitude, watershed sediment supply, increased tidal prism, or relative deepening due to sea-level rise. Similar relationships between geomorpholo- 


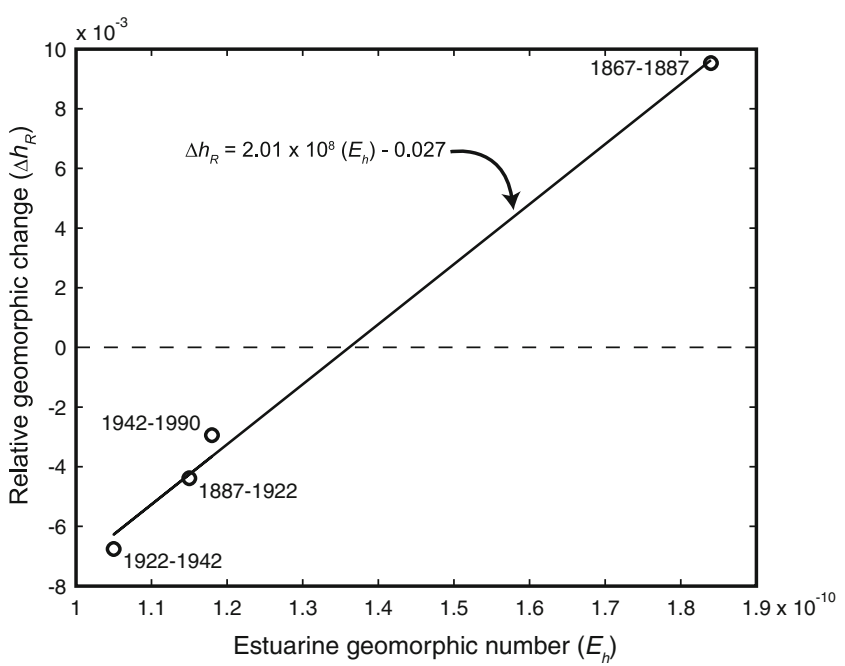

Fig. 7 Relationship between the dimensionless estuarine geomorphic number and relative geomorphic change for Suisun Bay. Year ranges correspond to bathymetric surveys of Cappiella et al. (1999)

gy and forcing for tidal inlets and river mouths (e.g., Jarrett 1976; Prandle 2004) demonstrate the efficacy of simple metrics for assessing geomorphic change. In these cases, increasing energy, in the form of tidal prism or river flow, tends to increase depth and/or cross-sectional area.

\section{Conclusions}

After calibrating and applying the Regional Ocean Modeling System (ROMS) model to tidal, annual, and decadaltimescale processes, it is suitable for use in evaluating future geomorphic evolution. Future scenarios of global warming, sea-level rise, and decreased watershed sediment supply may combine to modulate geomorphic evolution in Suisun Bay, thereby altering habitat distribution. We have applied the model to four scenarios: (1) base-case; (2) warming and sea-level rise; (3) decreased watershed sediment supply and sea-level rise; and (4) warming, decreased watershed sediment supply, and sea-level rise. Sea-level rise resulted in a reduction in wave orbital velocity, reducing sediment redistribution and promoting overall sediment deposition in the shallowest $2 \mathrm{~m}$ of Suisun Bay, while decreased watershed sediment supply decreased deposition through most of Suisun Bay. The moderate warming signal of 2030, reflected in altered streamflow timing and magnitude, had the most minor effect on overall geomorphic change. However, changes by the end of the twenty-first century may be sufficient to alter the sediment transport patterns within Suisun Bay. In all cases, the observed net deposition (and deposition in the shallowest $2 \mathrm{~m}$ ) was not sufficient to counteract the increase in sea level, which has ramifications for intertidal and marsh areas of Suisun Bay. Changes in optical depth or light penetration are dependent on a balance between decreasing suspended-sediment concentrations and sealevel rise; these two forces counteract to produce small changes in optical depth.

While this study does not consider climatic changes such as extended drought, the relative effect of drier years as opposed to wetter years is quantified. Drier years allow more landward sediment transport from San Pablo Bay, which currently has a stable supply of sediment. Under present-day watershed sediment yield conditions, San Pablo Bay is an important source of sediment to Suisun Bay. If future climatic changes favor drought as opposed to wet or normal conditions, the seaward end of Suisun Bay may become relatively more depositional, while the landward end becomes relatively more erosional. This may dictate whether Suisun Bay imports sufficient sediment to maintain intertidal and marsh habitat and also suggests that the composition of deposited sediment will reflect a more seaward source.

One ultimate product of this effort is a scaling analysis that relates relative geomorphic change to watershed sediment supply, depth, and tidal prism of the estuary. Processes favoring deposition, such as watershed sediment supply, are balanced against erosional processes such as tidal velocities and wind-wave resuspension. The dimensionless number developed here, the estuarine geomorphic number, is linearly related to relative geomorphic change in Suisun Bay. This analysis can be applied to other estuaries,
Table 5 Parameters used for calculation of relative geomorphic change and estuarine geomorphic number

Data taken from Cappiella et al. (1999), Krone (1979), and Ganju et al. (2008). Tidal prism $\left(Q_{\mathrm{p}}\right)$ and bed density $\left(\rho_{\mathrm{s}}\right)$ are held constant due to limited data

\begin{tabular}{lllll}
\hline Parameter & $1867-1887$ & $1887-1922$ & $1922-1942$ & $1942-1990$ \\
\hline$h(\mathrm{~m})$ & 3.15 & 3.13 & 3.55 & 4.08 \\
$\Delta h(\mathrm{~m} /$ year $)$ & 0.03 & -0.014 & -0.024 & -0.012 \\
$\Delta h_{\mathrm{R}}(1 /$ year $)$ & 0.0095 & -0.0044 & -0.0068 & -0.0029 \\
$Q_{\mathrm{s}} / Q\left(\mathrm{~kg} / \mathrm{m}^{3}\right)$ & 0.33 & 0.21 & 0.13 & 0.10 \\
$Q_{\mathrm{p}}\left(\mathrm{m}^{3}\right)$ & $1.05 \times 10^{8}$ & $1.05 \times 10^{8}$ & $1.05 \times 10^{8}$ & $1.05 \times 10^{8}$ \\
$\rho_{\mathrm{d}}\left(\mathrm{kg} / \mathrm{m}^{3}\right)$ & 529 & 529 & 529 & 529 \\
$E_{\mathrm{h}}$ & $1.84 \times 10^{-10}$ & $1.15 \times 10^{-10}$ & $1.05 \times 10^{-10}$ & $1.18 \times 10^{-10}$ \\
\hline
\end{tabular}


leading to general insight into the geomorphic forces in estuaries over the decadal timescale.

Acknowledgments This study was supported by the US Geological Survey's Priority Ecosystems Science program, CALFED Bay/ Delta Program, and the University of California Center for Water Resources. Use of ROMS and the CSTMS was supported by the US Geological Survey, with assistance from John Warner. This article is contribution no. 14 to the CASCADE project (Computational Assessments of Scenarios of Change for the Delta Ecosystem, Project \# SCI-05-C01-84). Any opinions, findings, and conclusions or recommendations expressed in this material are those of the authors and do not necessarily reflect the views of the CALFED Science Program. Input from Dano Roelvink, Mick van der Wegen, and the anonymous reviewers greatly improved the quality of the manuscript.

Open Access This article is distributed under the terms of the Creative Commons Attribution Noncommercial License which permits any noncommercial use, distribution, and reproduction in any medium, provided the original author(s) and source are credited.

\section{References}

Ariathurai, R., and K. Arulanandan. 1978. Erosion rates of cohesive soils. Proceedings of the American Society of Civil Engineering, Journal of the Hydraulics Division 104: 279-283.

Cappiella, K., C. Malzone, R. Smith, and B. Jaffe. 1999. Sedimentation and bathymetry changes in Suisun Bay, 1867-1990. U.S. Geological Survey Open-File Report 99-563.

Chubarenko, I., and I. Tchepikova. 2001. Modelling of man-made contribution to salinity increase into the Vistula Lagoon (Baltic Sea). Ecological Modelling 138: 87-100.

Cloern, J.E. 2007. Habitat connectivity and ecosystem productivity: Implications from a simple model. American Naturalist 169: E21-E33.

Coastal Engineering Research Center. 1984. Shore protection manual. Vicksburg: U.S. Army Corps of Engineers, Waterways Experiment Station.

Day, J.W., J. Rybczyk, F. Scarton, A. Rismondo, D. Are, and G. Cecconi. 1999. Soil accretionary dynamics, sea-level rise and the survival of wetlands in Venice Lagoon: A field and modelling approach. Estuarine, Coastal and Shelf Science 49: 607-628.

Fenster, M.S., and D.M. Fitzgerald. 1996. Morphodynamics, stratigraphy, and sediment transport patterns of the Kennebec River estuary, Maine, USA. Sedimentary Geology 107: 99-120.

Flick, R.E., J.F. Murray, and L.C. Ewing. 2003. Trends in the United States tidal datum statistics and tide range. Journal of Waterway, Port, Coastal, and Ocean Engineering 129: 155-164.

Ganju, N.K., and D.H. Schoellhamer. 2006. Annual sediment flux estimates in a tidal strait using surrogate measurements. Estuarine, Coastal and Shelf Science 69: 165-178.

Ganju, N.K., and D.H. Schoellhamer. 2009. Calibration of an estuarine sediment transport model to sediment fluxes as an intermediate step for robust simulation of geomorphic evolution. Continental Shelf Research 29: 148-158.

Ganju, N.K, N., Knowles, and D.H., Schoellhamer. 2008. Temporal downscaling of decadal sediment load estimates to a daily interval for use in hindcast simulations. Journal of Hydrology, 349: 512-523.

Ganju, N.K., D.H. Schoellhamer, and B.E. Jaffe., 2009. Hindcasting of decadal-timescale estuarine bathymetric change with a tidal- timescale model. Journal of Geophysical Research-Earth Surface 114, F04019, doi:10.1029/2008JF001191.

Gilbert, G.K. 1917. Hydraulic mining debris in the Sierra Nevada. U.S. Geological Survey Professional Paper 105, 148 pp.

Guillén, J., and A. Palanques. 1997. A historical perspective of the morphological evolution in the lower Ebro river. Environmental Geology 30: 174-180.

Hibma, A., H.J. de Vriend, and M.J.F. Stive. 2003. Numerical modeling of shoal pattern formation in well-mixed elongated estuaries. Estuarine, Coastal and Shelf Science 57: 981-991.

Jaffe, B.E., R.E. Smith, and L.Z. Torresan. 1998. Sedimentation and bathymetric change in San Pablo Bay: 1856 to 1983. U.S. Geological Survey Open-File Report 98-759.

Jaffe, B.E., R.E. Smith, and A.C. Foxgrover. 2007. Anthropogenic influence on sedimentation and intertidal mudflat change in San Pablo Bay, California: 1856-1983. Estuarine, Coastal and Shelf Science 73: 175-187.

Jarrett, J.T. 1976. Tidal prism-inlet relationships. General Investigations of Tidal Inlets Report 3, U.S. Army Engineer Waterways Experiment Station, Vicksburg, Mississippi, $32 \mathrm{pp}$.

Knowles, N., and D. Cayan. 2002. Potential effects of global warming on the Sacramento/San Joaquin watershed and the San Francisco estuary. Geophysical Research Letters 29: 38-1.

Krone, R.B. 1979. Sedimentation in the San Francisco Bay system. In San Francisco Bay: The urbanized estuary, ed. T.J. Conomos, 85-96. San Francisco: Pacific Division of the American Association for the Advancement of Science.

Le, T.V.H., H.N. Nguyen, E. Wolanski, T.C. Tran, and S. Haruyama. 2007. The combined impact on the flooding in Vietnam's Mekong River delta of local man-made structures, sea level rise, and dams upstream in the river catchment. Estuarine, Coastal and Shelf Science 71: 110-116.

Lesser, G.R., J.A. Roelvink, J.A.T.M. van Kester, and G.S. Stelling. 2004. Development and validation of a three-dimensional morphological model. Coastal Engineering 51: 883-915.

Lopez, C.B., J.E. Cloern, T.S. Schraga, A.J. Little, L.V. Lucas, J.K. Thompson, and J.R. Burau. 2006. Ecological values of shallowwater habitats: Implications for restoration of disturbed ecosystems. Ecosystems 9: 422-440.

Madsen, O.S. 1994. Spectral wave-current bottom boundary layer flows. Proceedings, 24th International Conference Coastal Engineering Research Council, 384-398.

Meehl, G.A., T.F. Stocker, W.D. Collins, P. Friedlingstein, A.T. Gaye, J.M. Gregory, A. Kitoh, R. Knutti, J.M. Murphy, A. Noda, S.C. B. Raper, I.G. Watterson, A.J. Weaver, and Z.C. Zhao. 2007. Global climate projections. In Climate change 2007: The physical science basis, ed. S. Solomon, D. Qin, M. Manning, Z. Chen, M. Marquis, K.B. Averyt, M. Tignor, and H.L. Miller. Cambridge: Contribution of Working Group I to the Fourth Assessment Report of the Intergovernmental Panel on Climate Change, Cambridge University Press.

Pethick, J. 1993. Shoreline adjustments and coastal management: Physical and biological processes under accelerated sea-level rise. The Geographical Journal 159: 162-168.

Pont, D., J.W. Day, P. Hensel, E. Franquet, F. Torre, P. Rioual, C. Ibanez, and E. Coulet. 2002. Response scenarios for the deltaic plain of the Rhone in the face of an acceleration in the rate of sealevel rise with special attention to Salicornia-type environments. Estuaries 25: 337-358.

Prandle, D. 2004. How tides and river flows determine estuarine bathymetries. Progress in Oceanography 61: 1-26.

Roelvink, J.A. 2006. Coastal morphodynamic evolution techniques. Coastal Engineering 53: 277-287.

Roy, P.S., R.J. Williams, A.R. Jones, I. Yassini, P.J. Gibbs, B. Coates, R.J. West, P.R. Scanes, J.P. Hudson, and S. Nichol. 2001. 
Structure and function of South-east Australian estuaries. Estuarine, Coastal and Shelf Science 53: 351-384.

Ryan, H.F., H. Gibbons, J.W. Hendley II, and P. Stauffer. 1999. El Niño sea-level rise wreaks havoc in California's San Francisco Bay region. U.S. Geological Survey Fact Sheet 175-99, 4.

Saintilan, N. 2004. Relationships between estuarine geomorphology, wetland extent and fish landings in New South Wales estuaries. Estuarine, Coastal and Shelf Science 61: 591-601.

Schoellhamer, D.H., and J.R. Burau. 1998. Summary of findings about circulation and the estuarine turbidity maximum in Suisun Bay, California. U.S. Geological Survey Fact Sheet FS-047-98, 6.

Shchepetkin, A.F., and J.C. McWilliams. 2005. The Regional Ocean Modeling System (ROMS): A split-explicit, free-surface, topography-following coordinates ocean model. Ocean Modelling 9: 347-404.

Simas, T., J.P. Nunes, and J.G. Ferreira. 2001. Effects of global climate change on coastal salt marshes. Ecological Modelling 139: $1-15$.

Sutherland, J., A.H. Peet, and R.L. Soulsby. 2004. Evaluating the performance of morphological models. Coastal Engineering 51: 917-939.

Walling, D.E. 2006. Human impact on land-ocean sediment transfer by the world's rivers. Geomorphology 79: 192-216.
Warner, J.C., W.R. Geyer, and J.A. Lerczak. 2005. Numerical modeling of an estuary: A comprehensive skill assessment. Journal of Geophysical Research 110: C050001.

Warner, J.C., C.R. Sherwood, R.P. Signell, C.K. Harris, and H.G. Arango. 2008. Development of a three-dimensional, regional, coupled wave-, current-, and sediment-transport model. Computers and Geosciences 34: 1284-1306.

Woodruff, J.D., W.R. Geyer, C.K. Sommerfield, and N.W. Driscoll. 2001. Seasonal variation of sediment deposition in the Hudson River estuary. Marine Geology 179: 105-119.

Wright, L.D., and C.A. Nittrouer. 1995. Dispersal of river sediments in coastal seas: Six contrasting cases. Estuaries 18: 494-508.

Wright, S.A., and D.H. Schoellhamer. 2004. Trends in the sediment yield of the Sacramento River, California, 1957-2001. San Francisco Estuary and Watershed Science, 2, Article 2.

Wright, S.A., and D.H. Schoellhamer. 2005. Estimating sediment budgets at the interface between rivers and estuaries with application to the Sacramento-San Joaquin River Delta. Water Resources Research 41: W09428. doi:10.1029/2004WR003753.

Yang, S.L., I.M. Belkin, A.I. Belkina, Q.Y. Zhao, J. Zhu, and P.X. Ding. 2003. Delta response to decline in sediment supply from the Yangtze River: Evidence of the recent four decades and expectations for the next half-century. Estuarine, Coastal and Shelf Science 57: 689-699. 